\title{
Earthquake Damage Assessment in the Traditional Town of Sankhu, Kathmandu
}

\author{
Sudha Shrestha ${ }^{1}$, Ashim R. Bajracharya ${ }^{1}$, Luna Bajracharya ${ }^{1}$, Nisha Shrestha ${ }^{1}$, Monika Maharjan ${ }^{2}$ \\ ${ }^{1}$ Centre for Urban Planning Studies (CUPS), South Asia Urban Knowledge Hub \\ Institute of Engineering, Tribhuvan University \\ ${ }^{2}$ Ministry of Urban Development (MoUD), Govt. of Nepal \\ Corresponding author: cups.k-hub@ioe.edu.np
}

Received: March 7, 2016 Revised: July 4, 2016 Accepted: July 15, 2016

\begin{abstract}
Nepal Earthquakes 2015 April and may caused huge loss of lives and properties in the country. Several traditional buildings and monuments in the Kathmandu Valley were literally collapsed to the ground, completely changing the built form of several traditional towns such as Bungamati, Khokana, and Lubhu. In this regards, traditional town Sankhu is also not in an exception. According to the field survey, $90 \%$ of traditional houses were severely damaged in Sankhu. In this respect, this study was focused on rebuilding of Sankhu, preserving its traditional form and analyzing it from economic perspective. The study was based on household survey and the respondents were selected as per their availability and willingness to participate in the research process. The traditional building construction technology is rich in terms of resilience against earthquakes, if it is well maintained. Maintenance and repair of building elements of traditional building is relatively simple, without affecting the building structure and other building elements, as compared to RCC structure. Sankhu is economically struggling town and, it is very important to rebuild the town in traditional style to bring back its original identity for its prosperity in trade and tourism. It is an opportunity to bring some of the lost glory of the past and its outstanding building and monuments.
\end{abstract}

Keywords: Sankhu, Traditional Newari Architecture, Earthquake Resilience, Damage assessment

\section{Introduction}

Nepal Earthquakes 2015 April caused huge loss of lives and properties in the country - about 9,000 casualties; 22,300 injuries, 8 million directly affected people (or $1 / 3 \mathrm{rd}$ of the national population), over half a million collapsed houses, and a drop by over 1.5 percentage points in gross domestic product $[9]^{1}$ Although the most affected regions were rural areas located outside the Kathmandu Valley, the latter also witnessed about 1700 casualties, 13,000 injuries, and 724,00

\footnotetext{
${ }^{1}$ In this document, the 2015 April-May Nepal Earthquakes refer collectively to the $7.8 \mathrm{Mw}$ Gorkha Earthquake of April 25, 2015 and 7.3 Mw earthquake of May 12, 2015.
} 
collapsed houses [2]. Several traditional buildings and monuments, world-renowned indigenous Newari architecture, in the Kathmandu Valley were literally collapsed to the ground, completely changing the built form of several traditional towns such as Bungamati, Khokana, Lubhu, and most notably Sankhu. In light of the destruction caused by the recent earthquakes, the Urban Knowledge Hub (K-Hub) initiative in Nepal - based at the Institute of Engineering and supported by the Asian Development Bank and the Ministry of Urban Development - intends to contribute towards informed policymaking on risk-resilient urban development through the development and promotion of knowledge products. Urban resilience is a city's ability to withstand and recover from unexpected shocks associated with natural hazards such as earthquakes [1]. Building urban resilience begins with the collection, management, and dissemination of information on damage and prevailing risks. This case study takes stock of building damage in Sankhu in order to provide informed insight on how the town can be 'built back better'. ${ }^{2}$

As a town known for its heritage in the form of traditional architecture and built environment, the reconstruction of Sankhu could go either way: its historical built form could be adhered to, or there could be a departure in favour of 'modern' development. The complete collapse of traditional buildings has left a false impression that traditional building technology is not safe against earthquakes. However, these very buildings built with indigenous and ingenious building technology earlier survived the powerful 1934 Bihar Earthquake.

\section{Study Area: Sankhu}

Sankhu is an ancient town (12.5 hectares) populated by the Newars, the original inhabitants of the Kathmandu Valley. Sankhu is one of the oldest settlements in the Kathmandu Valley, situated about $20 \mathrm{~km}$ northeast of Kathmandu city (Fig. 1) on the bank of Salinadi River, established by the Licchavis. The oldest inscription found in Sankhu is dated 538 AD [8]. Until recently, the town was a part of the three erstwhile Village Development Committees (VDCs) - Pukhulachhi, Suntol and Vajrayogini. Sankhu now forms the historic core area of recently declared Shankharapur Municipality. Once flourished as a trade post on the route to Tibet, Sankhu began to lose competitive advantage with the loss of this route in the late 1950s with further damage caused by the construction of Araniko Highway that now linked Kathmandu to the Tibetan border via Bhaktapur. Though most of the smaller traditional towns depended heavily on agriculture, Sankhu has historically been relatively less dependent on agriculture. Even in a survey conducted by HMG/N (1969) [2], about 30 percent of the households reported non-agricultural occupation (e.g., commerce, wage employment or industries) as their primary occupation. The loss of trade to Tibet led to an increasing number of families seeking employment elsewhere, and even permanently migrating to other towns.

\footnotetext{
${ }^{2}$ The 'Build Back Better' or BBB implies a common approach adopted the government and development partners for the post-earthquake reconstruction in Nepal. The 'Build Back Better' approach basically "advocates for the restoration of communities and assets in a manner that makes them less vulnerable to disasters and strengthens their resilience.” (UN World Conference on Disaster Risk Reduction, 2015).
} 


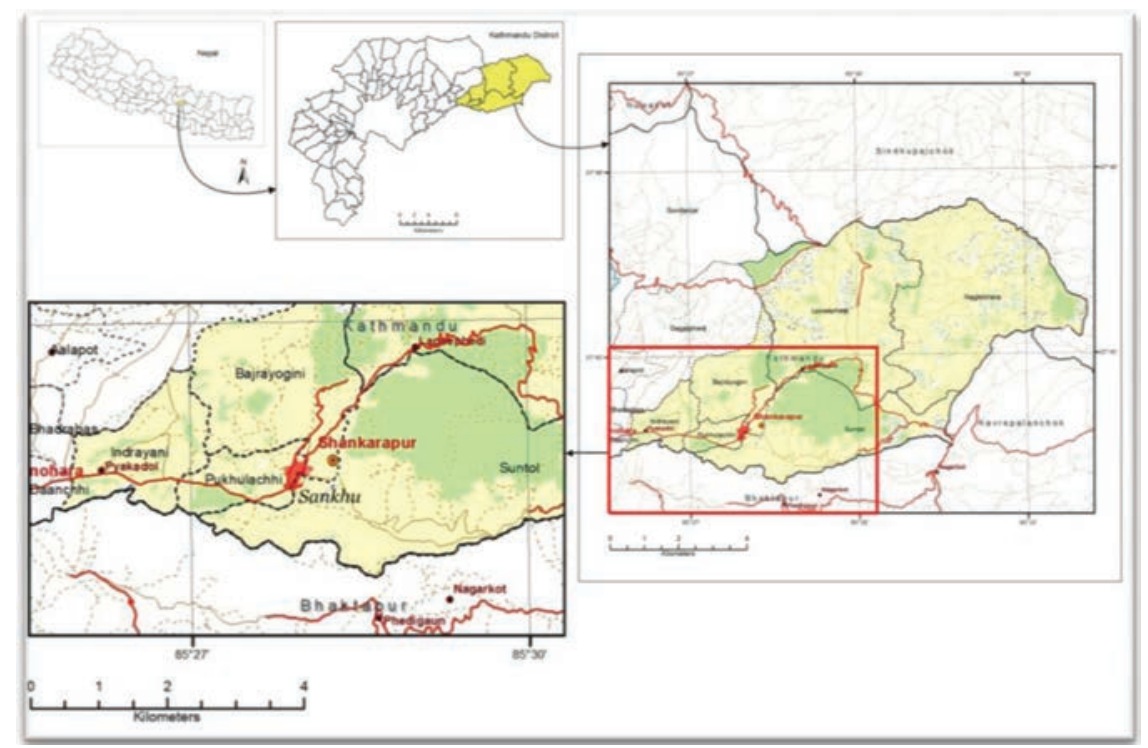

Fig. 1: Regional map of Sankhu

Settlement Pattern: Like any other ancient town in the Kathmandu Valley, Sankhu is a compact settlement. Aside from the historic necessity for defense and the need for proximity to cultivated farmlands, the compact form of vertically oriented living in Sankhu - or any Newar town for that matter is strongly motivated by concerns to preserve rich farmlands and minimize their use for residential purposes. With the abundance of clay in those times, houses have been uniformly built of burnt and un-burnt clay bricks. The streets are mostly brick paved and the houses, of rather uniform height seldom exceeding $3 \frac{1}{2}$ stories, built on either side of the streets have at least the brick walls of the compounds adjoining. Houses are closely spaced - built back to back with only a narrow lane between the two buildings.
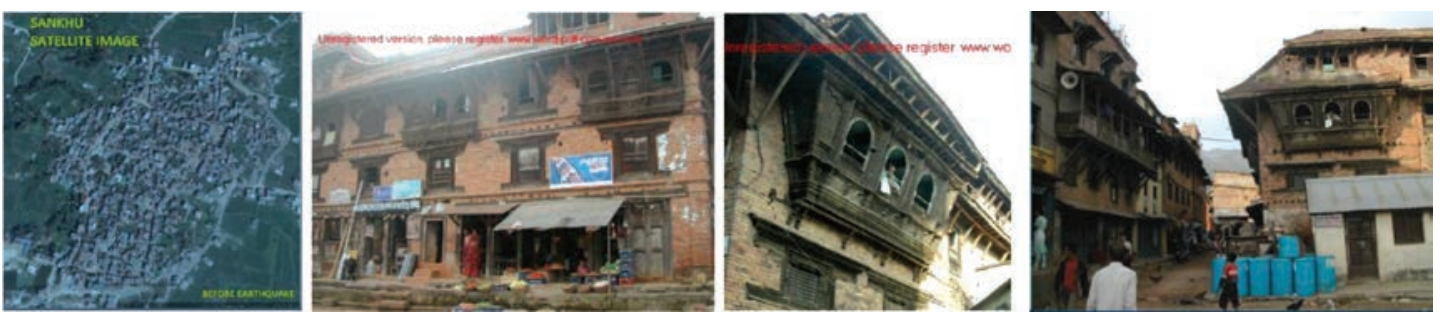

Fig. 2: Map and pictures of architecturally outstanding building and alleys of Sankhu

(Courtesy: Sankhu Reconstruction Committee)

Frequently narrow lanes lead from the main road into the maze of houses. Small openings link with narrow lanes to the courtyards lying behind the house-fronts. The compact settlement and its neighborhoods are designed in such a way that narrow lanes leading wider streets, courtyards and squares give scene of wonder. In addition to that, one of the interesting aspects of Newari traditional towns exist arrangement of open spaces all over town, which helps in performing daily social, cultural and economic activities of people living there. Courtyards are surrounded by buildings on all sides, or sometimes on three sides with the fourth one replaced either by a pond or a well with a gate. The enclosed courtyard, though originally designed for providing protection, 
also provides access to private dwellings. There are five different entrance gates constructed in different locations of the boundary wall of the town. Different gates are using in different purposes such as one gate for welcoming bride (daughter in-law) to the town and another gate for farewell of daughters of Sankhu from the town to another parts of country. Likewise one gate is use for bring Goddess Bajrayogini inside the town and another gate is use to take dead body to the crematorium. The shape of the town itself is very interesting; it is a form of Cong cell.

\section{Data Collection for Assessing Damage Situation}

\subsection{Household Survey}

The total number of completely damaged houses was found to be 1051and partially damaged houses were found to be 365; altogether 1416 houses were damaged in Sankhu. For the survey, from the list of damaged houses, houses of Newar community were taken into account. Since many of the houses were completely damaged, the owners of those damaged houses were not present at the site. Thus, accidental (convenience) sampling method was used for the study. The respondents were selected as per their availability and willingness to participate in the research process. The sample size was taken from total number of damaged building in the core settlement area of Sankhu which lies within four wards: ward number 8,9,10 and 11.

Therefore, Household survey of 80 affected traditional houses was conducted in different parts of Sankhu to assess the damage situation.

\subsection{Field Observations}

Site visit and observation of different places was made for the study. Photographic documentation was done to know about different places of Sankhu along with the damage situation after the earthquake.

\subsection{Review of Previous Assessment done}

Damage in Sankhu was extensive and among damaged houses, most of brick and cement mortar houses (load bearing houses) without RCC columns experienced a lot of damage. In contrast, the damage to building with RCC structures, constructed in recent years has minor damage. These structures were mainly five to six story buildings. Non-engineered masonry structures which were completely collapsed or partial damaged were two to four story buildings. Damage in nonengineered masonry structures were initiated by vertical cracks in the corners of the buildings. The outer wall structures of such buildings were generally burnt brick with cement mortar joints. In several cases, the inner walls of buildings are sun dried bricks with mud mortar [5].

\section{Earthquake Damage in Sankhu: The Building Sector}

\subsection{An Overview of Building Damage}

More than 90 percent of the buildings in Sankhu, mostly traditional houses were completely damaged in the recent earthquakes, according to official figures from NSET. Sankhu core comprises of ward no. 8, 9, 10 and 11, some attempts have been made to estimate losses in the core area alone.

According to a survey done by NSET (August, 2015), out of about one thousand buildings in Sankhu, traditional buildings $70 \%$ and modern buildings $24 \%$, and the rest were neo-classical 
buildings (1\%) and others (5\%) were collapsed. Out of assessed 631 traditional buildings, 93\% of the buildings suffered substantial damage and more, including complete destruction of $70 \%$ traditional buildings. In contrast, out of 217 assessed modern buildings, 22\% suffered substantial damage and more including complete collapse of $5 \%$ (Table 1, Fig. 3).
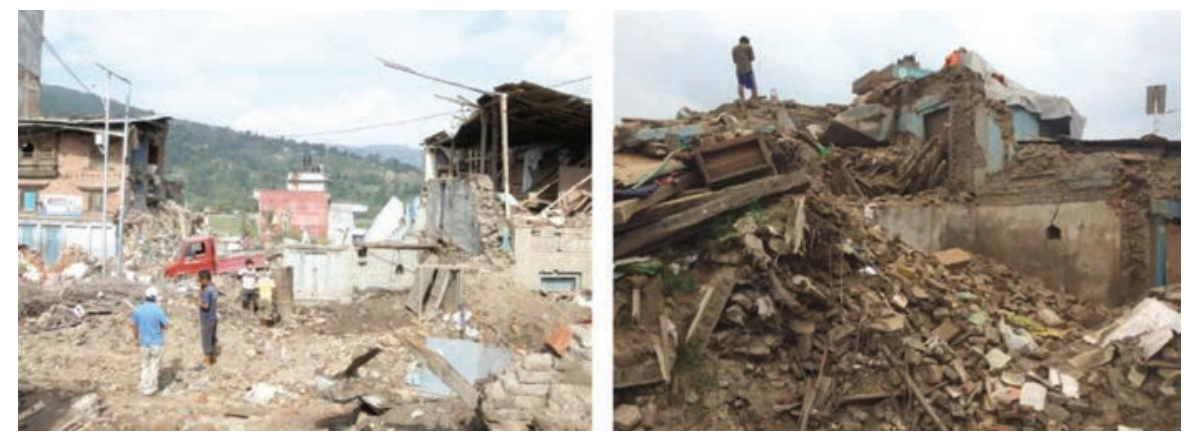

Fig. 3: Earthquake damage in Sankhu

Table 1: Building damage in Sankhu

\begin{tabular}{lcccccc}
\hline \multirow{2}{*}{ Building Type } & \multicolumn{4}{c}{ Damage Grade (DG) } & \multicolumn{1}{c}{ Total No. of } \\
\cline { 2 - 6 } & DG1 & DG2 & DG3 & DG4 & DG5 & Assessed Buildings ** \\
\hline Traditional: Malla Newari architecture & 32 & 13 & 29 & 115 & 442 & 631 \\
Neo-classical: Rana style & 142 & 27 & 15 & 22 & 11 & 217 \\
Modern: RCC buildings & 1 & & & 2 & 2 & 5 \\
Others: Sheds, factory, store, mills, etc. & 3 & 1 & 1 & 2 & 6 & 13 \\
\hline Total & 178 & 41 & 45 & 141 & 461 & 866 \\
\hline
\end{tabular}

(Source: NSET, 2015)

Note: DG1: negligible damage; DG2: moderate damage; DG3: substantial to heavy damage; DG4: very heavy damage; and DG5: destruction.** There are in total about one thousand buildings in Sankhu.

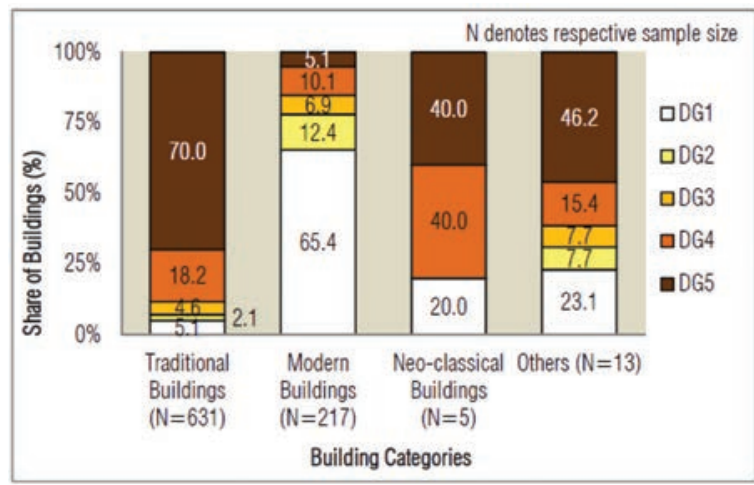

Fig. 4: Share of buildings according to types and damage grade

(Source: NSET, 2015) 


\subsection{Damage of Buildings}

In the survey of 80 affected-households, 68 buildings had completely collapsed and 12 were partially damaged. Among the surveyed households of 73 traditional buildings built in mud mortar, $37 \%$ reported that damage to their buildings was caused by neighboring buildings (possibly pounding effect), and 55\% blamed old age. When asked why the buildings were not maintained, the concerned households listed replacement of jhingati roof tiles with corrugated galvanized iron sheets or plastering of walls as maintenance. These traditional buildings need skill knowledge for repair and maintenance. There was not sufficient awareness about the structural retrofitting and maintenance of the buildings.

The household sample survey indicates a significant loss of houses. Prior to the earthquake damage, most of the surveyed households had 4-storied buildings, and most buildings had at least 2 rooms per floor. The household size was large - 68\% (55 out of 80 ) of the surveyed households had 5 or more members (Fig. 5).

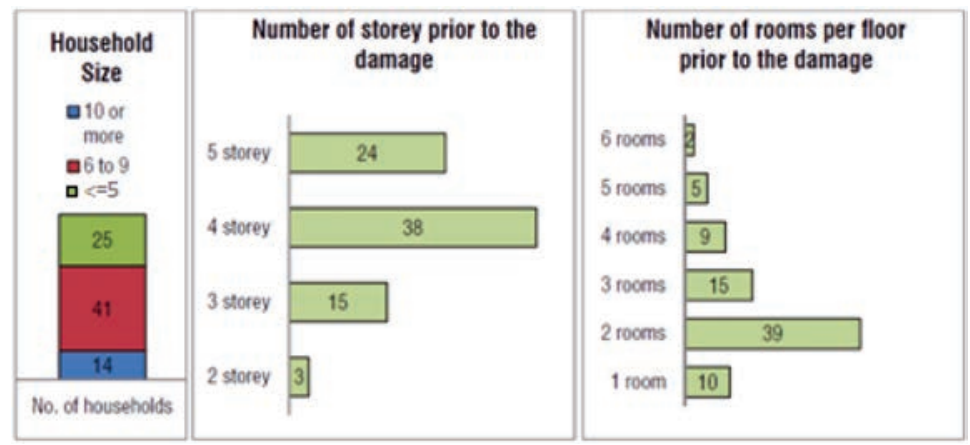

Fig. 5: Household size in surveyed households (left), number of storey (middle) and rooms per floor (right) prior to the damage

\subsection{Building Typology and Fragility}

The fragility of building structures during earthquakes depends on the building typology and construction technology adopted. Like in every other urbanizing areas of the country, it is common to see buildings of different types and ages (periods) standing next to one another in Sankhu although majority of the buildings are still traditional brick-in-mud mortar types.

It is evident that if not built properly, masonry buildings are prone to total collapse (damage grade or DG5) in strong earthquake [7]. The same fate awaits for non-engineered reinforced concrete (RC) structures" with four or more stories. This implies that a reinforced concrete structure - commonly known in public discourse as 'pillar system' - does not automatically ensure immunity against total collapse. The point is to construct a moment-resisting frame structure or 'engineered' building whereby lateral forces are resisted by the reinforced concrete frames that develop their stiffness through monolithic beam-column connections." This technical difference between engineered and non-engineered RC structures makes all the difference during strong earthquakes as evident from complete collapse of several RC buildings in the affected districts.

However, in Sankhu, the survival of RC buildings (including non-engineered ones), though a matter of relief, may promote public bias against masonry buildings. Traditional Building if built well, even brick-in-mud and certainly brick-in-cement buildings can perform well against strong 
seismic force [7]. This is important from the perspective of preserving or reviving traditional architecture and built environment of Sankhu which is now important for the economic recovery of the ancient town.

It is also important to note that incremental vertical expansion of buildings is very prevalent in urban Nepal; Sankhu is also not an exception. This often results into an incompatible mix of new stories - often brick-in-cement types or even concrete structures - over old mud mortar stories, ageing lower stories which are now forced to withstand the unintended load. In terms of seismic behavior, such buildings are the opposite of a monolithic structure, and hence very vulnerable to earthquake damages.

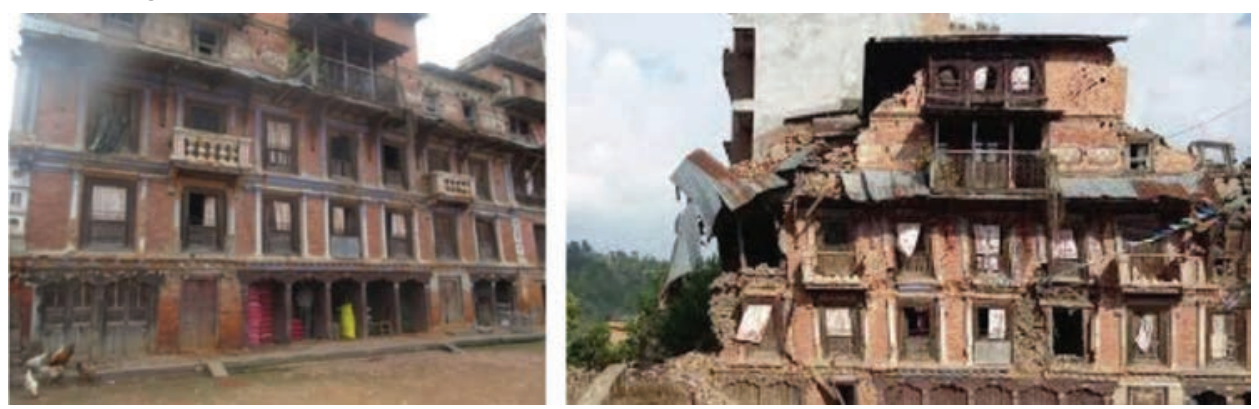

Fig. 6: Salkha Tole- before (left) and after (right)

(Courtesy: Sankhu Reconstruction Committee)
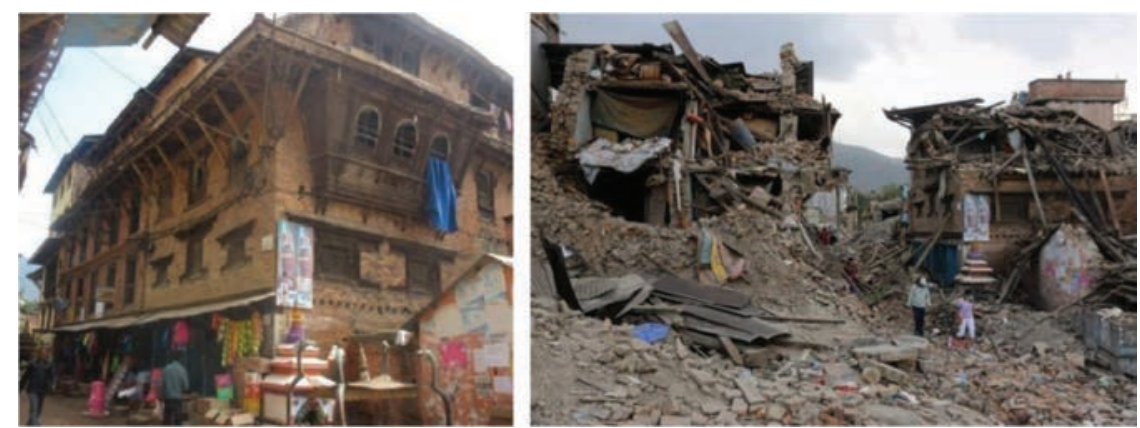

Fig. 7: Salkha tole- before (left) after (right)

(Courtesy: Sankhu Reconstruction Committee)
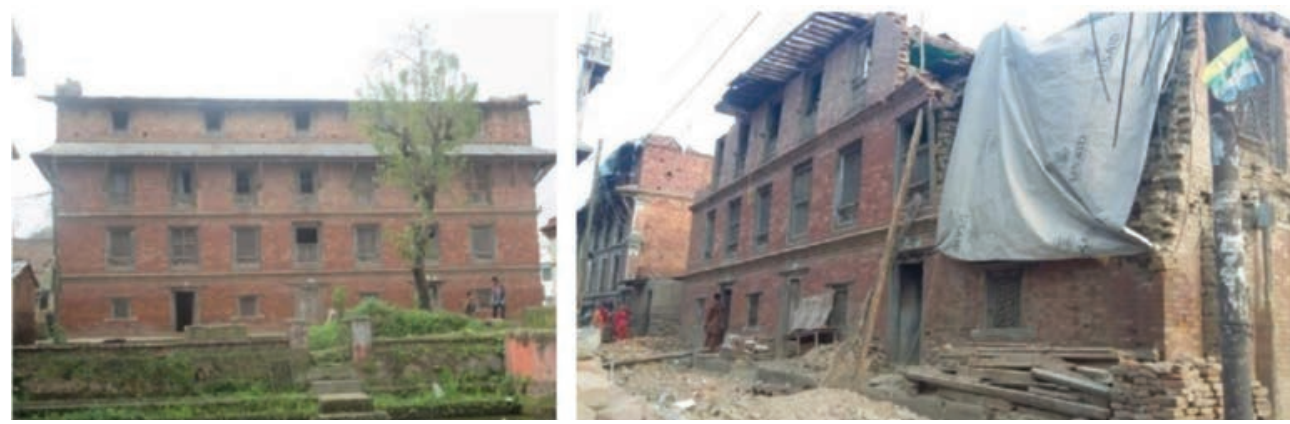

Fig. 8: Pukhulachhi Tole- before (left) and after (right)

(Courtesy: Sankhu Reconstruction Committee) 

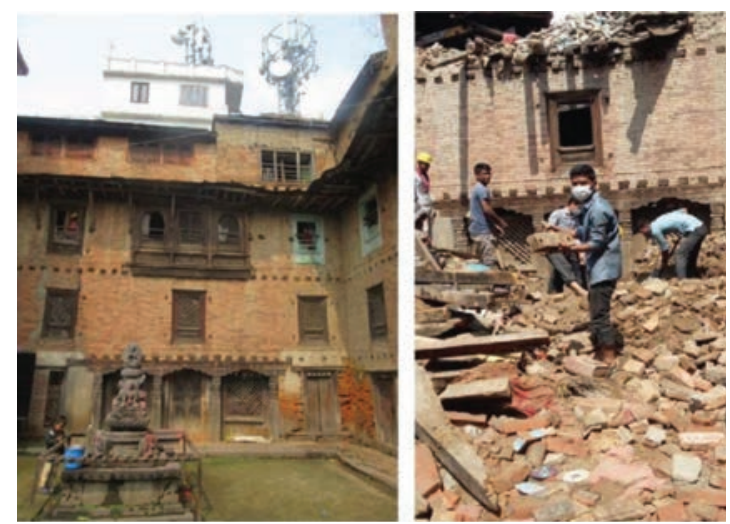

Fig. 9: Dhunla Tole- before (left) and after (right)

(Courtesy: Sankhu Reconstruction Committee)

\subsection{Shape and mass irregularities:}

Many new buildings constructed in Sankhu and elsewhere display irregular shapes and forms in the name of innovative design and experimental architecture. However, shape irregularities and associated mass irregularities add vulnerability to buildings during earthquakes because of reduced stability of structures by design.
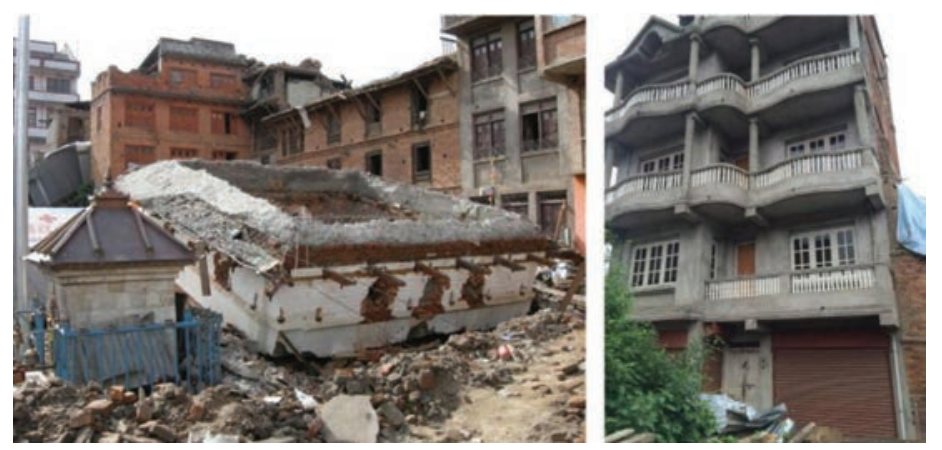

Fig. 10: Pancake failure of a Sankhu temple (Left), soft storey on ground floor in a tall building in Sankhu (right)
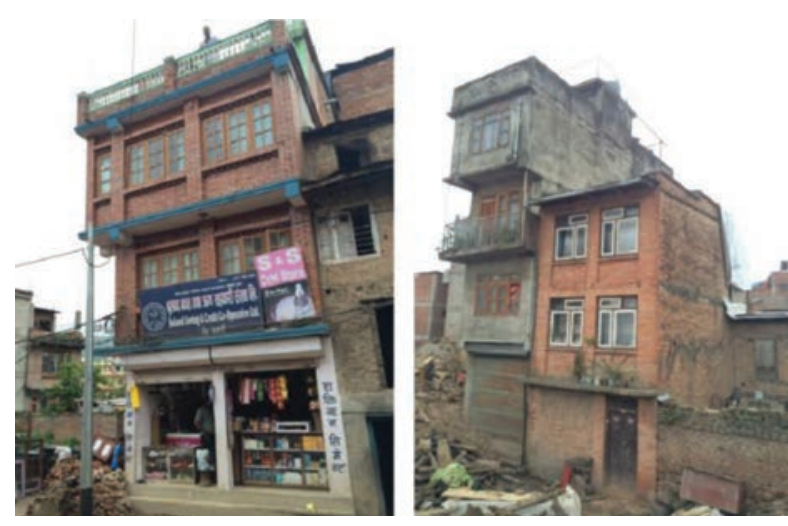

Fig. 11: Vertical irregularity in Sankhu buildings 
If buildings are built without sufficient gap and the interaction has not been considered, the buildings may pound each other during an earthquake (Fig. 10). Building pounding can alter the dynamic response of both buildings, and impart additional inertial loads on both structures. Buildings that are of the same height and that have matching floors will exhibit similar dynamic behavior. In such case, when the buildings pound, floors will impact other floors, so damage due to pounding usually will be limited to non-structural components. When the floors of adjacent buildings are at different elevations, floors will impact the columns of the adjacent building and can cause structural damage [7].

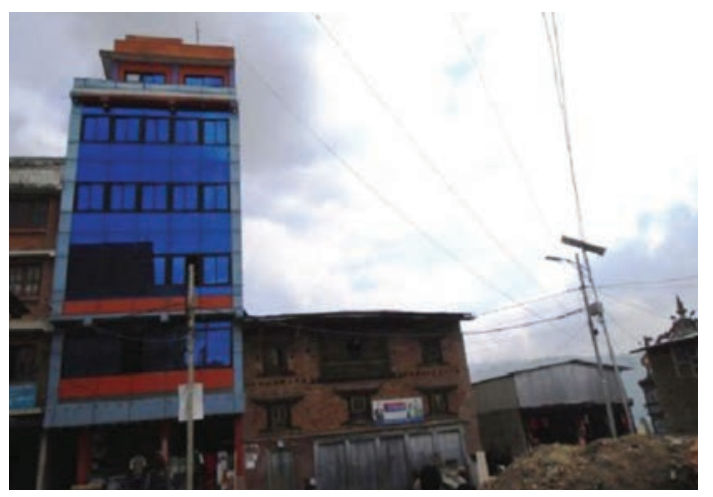

Fig. 12: Neighboring buildings of different heights in Sankhu

\subsection{Do traditional buildings have future?}

Since the loss of trade route to Tibet, Sankhu has been an economically depressed town. The town has witnessed out-migration of many well-to-do families, which implies not only brain drain but also capital drain. Traditional buildings which suffered heavy damage during the recent earthquakes were already in dire needs of repair. Lack of timely maintenance could be attributed to the economic conditions of the concerned households who chose to stay in Sankhu or who could not afford to leave Sankhu.

As already discussed, the traditional building construction technology allows repair of building elements non-intrusively. The technology is known and is documented. Besides the costs of repair, it is also the issue of whether traditional buildings are compatible for modern way of living whether the homeowners themselves would choose or decline traditional style while rebuilding their houses. According to the survey, the households of damaged buildings wished to see changes in building functions (e.g., use of ground floor for shops) and physical dimensions (e.g., increased floor height, room size) when they would rebuild (Fig. 13, left).

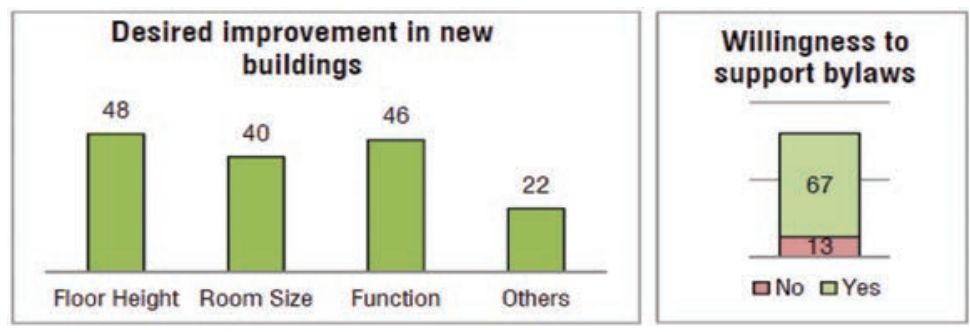

Fig. 13: Desired improvement in new buildings (left), willingness to support bylaws focused on traditional construction (right) 
Regarding the preservation of traditional built form at the building level, acceptance level was found to be almost $84 \%$ (Fig. 13, right). Respondents were asked whether they would support building bylaws that would require them to preserve or rebuild buildings in traditional styles. About $16 \%$ of the surveyed households opposed rebuilding in traditional manner citing reasons such as high costs, economic inability to invest, and incompatibility of traditional houses for modern way of living. Aside from the majority of the surveyed households, participants of the key in-formants interviews (KIIs) strongly supported the need to preserve the traditional identity of Sankhu even if some compromises in the form of improvisation would be required to suit modern way of living and to address seismic risks.

New Construction Byelaws: Recently, the Government of Nepal endorsed Fundamental Construction Byelaws on Settlement Development, Urban Planning and Building Construction 2015 focusing on developing safer communities to deal with future disaster risks after Nepal Earthquake 2015.

Accordingly, new municipalities, such as Sankharapur Municipality of which Sankhu is a part, and VDCs are required to implement the byelaws. For provisions not listed in the Fundamental Byelaws 2015, the earlier byelaws - Building Byelaws 2064 BS - will continue. As per the latter, Sankhu falls under the category of Cultural Heritage Sub-Zone and Mixed Old Residential SubZone of Cultural Heritage Conservation Zone. However, now as a part of a new municipality and in the context of new Fundamental Construction Byelaws 2015, the nature of legal provisions for the (re)construction of buildings in Sankhu has become a matter of confusion for the residents of Sankhu. The residents are concerned that if the provisions outlines in the Fundamental Construction Byelaws 2015 regarding minimum lot size of 3 Anna (approx. 95 sq. m) and minimum right-ofway are of $6 \mathrm{~m}$ are to be followed; Sankhu can no way retain any of its traditional form. Its foot prints will no more remaining. Many houses in Sankhu are or were built on plots as small as less than 1 Anna such as 3 daam (approx. 24 sq. m). It is learnt that majority of Sankhu residents are suspicious about the so-called 'house pooling' approach of reconstruction - more in-depth study and perception survey is required.

\subsection{The Economic Perspective}

In order to retain the original built form of Sankhu to some extent practically possible, but the economic benefits should be clear. Emotionally charged strategies lose their relevance over time but decisions that also make economic sense should be long lasting. In any spatial planning, the strength of the settlement is its spaces and places, arrangement and organization of open spaces and places. Here the strength of Sankhu is its physical manifestation in the form of traditional buildings and its footprints, narrow alleys, courtyards, temples and interestingly laid open spaces, and more over its cultural heritage. [4]

In some core areas of Kathmandu Valley, some historic buildings have been remodeled as bed-andbreakfast inns or short-term residential rental units with impressive economic returns. The survey respondents and KII participants expressed optimism that reconstruction of Sankhu in traditional style would be economically beneficial as that would create investment opportunities related to tourism and service sector - buildings can partly be rented not only for tourism-related services but also for office use by government or nongovernment agencies. Municipality can play the role of facilitator.

To drive the point home, a very simple economic analysis (at building level) can be performed assuming that a 4 -storied building is to be built on a plot of 2 asana (684.5 sq.ft) with $100 \%$ 
ground coverage. The total built-up area is therefore 2738 sq.ft. Three alternative building styles are considered: (1) traditional, (2) semi-traditional, and (3) modern. Construction costs vary accordingly. Different rental areas (\%) are considered. For simplicity, floor rents are assumed to increase annually at the rate equivalent to the interest rate - this way, discounted amount equals the present value. The life of building is assumed to be 20 years, which is checked against calculated payback period. The operation and maintenance (O\&M) cost is supposed to be $30 \%$ of the gross rental income.

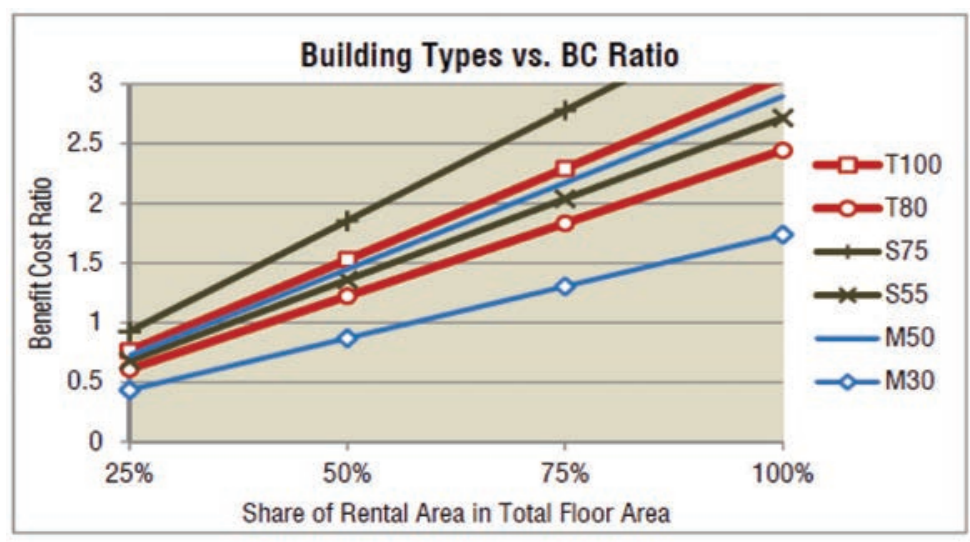

Fig. 14: Building types versus $B C$ ratio

\subsection{Policy Response}

Most of the prevailing policies do support preservation of traditional buildings but the policies are mostly restrictive, telling homeowners what they can do or cannot do rather than addressing their economic benefit. If a traditional building has social value, what does its homeowner receive in lieu of preserving the building? This is an important question. Lack of interest in the maintenance of traditional buildings or their continued replacement by 'modern' style buildings implies that the welfare of the homeowners of traditional buildings is not being taken care of.

Here the problem is government did not emphasis on traditional building construction technology and other hand the technology itself is very expensive compare to other construction technology but at the same time, repair and maintenance of traditional building is not so expensive. If people do maintenance in time, cost will be less. For conservation and preservation of traditional buildings and monuments, government has to have some subsidy provision and for the preservation of unique identity there should be plans and programs through multi-stakeholder participatory approach.

\section{Conclusions and Recommendations}

Crisis also provides opportunity. The devastation caused by the recent earthquakes has generated unprecedented public awareness on the importance of safe building construction and risk-resilient urban development. Although valuable lessons have been learnt, some myths have also crept in. The case in point is the massive destruction of traditional buildings, which may have left a false impression that traditional buildings are not safe against earthquakes. However, these same buildings have withstood earlier earthquakes including the powerful 1934 Bihar Earthquake. The traditional building construction technology is rich in terms of resilience against earthquakes as 
well as in terms of simplicity in the maintenance of building elements without impacting the other elements of the building. However, as investigated in this case study, traditional buildings failed miserably during the recent earthquakes because of their old age and lack of maintenance for a prolonged period. The underlying reasons for poor maintenance are high costs and low economic capacity of the concerned households. However, the economic opportunities associated with the preservation of traditional buildings have not been properly or fully explored. For an economically struggling town such as Sankhu, rebuilding in traditional style to bring back some of the lost glory could be an economic opportunity too.

\section{Acknowledgement}

This research has been carried out under support of Asian Development Bank (ADB) and Ministry of Urban Development (MoUD).

\section{References}

[1] Asian Development Bank. Moving from risk to resilience: sustainable urban development in the Pacific. Mandaluyong City, Philippines: Asian Development Bank, 2013. Available online at http://www.adb.org/sites/default/files/publication/31200/moving-risk-resilience-sustainableurban-development-pacific.pdf.

[2] HMG/N (1969). The Physical Development Plan for the Kathmandu Valley. His Majesty's Government of Nepal, Department of Housing and Physical Planning, Nepal.

[3] Korn W (1977), The Traditional Architecture of the Kathmandu Valley. Kathmandu: Ratna Pustak Bhandar.

[4] Licciardi G and Amirtahmasebi R (2012), The Economics of Uniqueness: Historic Cities and Cultural Heritage Assets as Public Goods. Washington DC: World Bank

[5] Tsuneo OHSUMI, Principal Research Fellow, Disaster Risk Unit, National Research Institute for Earth Science and Disaster Prevention (NIED), Japan Investigation of damage to buildings and groundtruth verification for satellite data in Kathmandu Valley due to the 2015 Gorkha Earthquake

[6] MOHA, Preliminary report prepared by the Ministry of Home Affairs available at http://drrportal. gov.np/ uploads/document/175.pdf.

[7] MOUD/UNDP (2011), Seismic Vulnerability Evaluation Guideline for Private and Public Buildings. Ministry of Urban Development! United Nations Development Programme, Nepal.

[8] Shrestha BG (2012), The Sacred Town of Sankhu: The Anthropology of Newar Ritual, Religion and Society in Nepal. UK: Cambridge Scholars Publishing.

[9] National Planning Commission (2015), Nepal Earthquake 2015 - Post Disaster Needs Assessment. Vol. A: Key Findings. Government of Nepal, National Planning Commission

[10] UN World Conference on Disaster Risk Reduction (2015), Reconstructing after disasters: Build back better (Ministerial Roundtable), Issue Brief. 14-18 March, Sendai, Japan. http://www. wcdrr.orgluploads/ Reconstructing-after-disasters-Build-back-better.pdf

[11] National Society for Earthquake Technology NSET (2015), A Presentation on Urban Regeneration in Post Earthquake Sankhu- Sankhu Old City Situation Survey and Analysis, Shankharapur Municipality, Nepal. 